\title{
Flipped classroom: Pedagogical model necessary to improve the participation of the students during the learning process
}

\author{
Ricardo-Adán Salas-Rueda \\ Instituto de Ciencias Aplicadas y Tecnología, Universidad Nacional Autónoma de México, Mexico
}

Nowadays, teachers can transform the organization and realization of school activities before, during and after the face-to-face sessions through the flipped classroom. The objective of this mixed research is to analyze the impact of the flipped classroom in the teaching-learning process on statistics considering data science and machine learning (linear regression). The sample consists of 61 students who took the Statistical Instrumentation for Business course during the 2018 school year. This research proposes the consultation of the YouTube videos before the class, performance of the collaborative exercises and use of the spreadsheet to check the results during the class and performance of the laboratory practices through the spreadsheet after the class. The results of machine learning (70\%, $80 \%$ and $90 \%$ of training) indicate that the participation of the students before, during and after the class positively influences the assimilation of knowledge and development of mathematical skills about the frequencies and measures of central tendency. On the other hand, the decision tree technique identifies 6 predictive models on the use of the flipped classroom. Also, the students of the Statistical Instrumentation for Business course are motivated and satisfied to use the technological tools in the Introduction to statistics Unit. Finally, the flipped classroom allows the construction of new educational spaces and creation of creative activities before, during and after the class that favor the participation of the students during the learning process.
Article Details

LUMAT General Issue

Vol 8 No 1 (2020), 271-296

Submitted 20 August 2020

Accepted 21 October 2020

Published 28 October 2020

Pages: 26

References: 27

Correspondence:

ricardo.salas@icat.unam.mx

https://doi.org/10.31129/ LUMAT.8.1.1394

Keywords: flipped classroom, technology, higher education, data science,

machine learning

\section{Introduction}

The society of the 21st century demands the use of the technological tools in the educational field to improve the learning process (Ignatova, Dagiene, \& Kubilinskiene, 2015; Ortiz-Colon, Muñoz-Galiano, \& Colmenero-Ruiz, 2017). Therefore, teachers search, select and use new pedagogical models to facilitate the assimilation of knowledge and develop the skills of the students (Deng \& Purvis, 2015; Karolcik, Cipkova, Hrusecky, \& Veselsky, 2015).

Information and Communication Technologies (ICTs) allow the creation of educational spaces that favor the active participation of the students inside and outside of the classroom (Salas-Rueda, 2020; Shih \& Tsai, 2017; Sun, 2017). In fact, 
the behavior and functions of the students are changing because teachers use the technological tools to organize and perform new school activities at any time and place (Salas-Rueda, Salas-Rueda, \& Salas-Rueda, 2020; Sadeck \& Cronje, 2017; Uyanga, 2014).

The flipped classroom is a pedagogical model that proposes the realization of the activities inside and outside the classroom (Shih \& Tsai, 2017; Sun, 2017). Therefore, the use of ICTs such as audiovisual contents (Lo, Lie, \& Hew, 2018), digital presentations (Burke \& Fedorek, 2017), web applications (Wang, 2017), technological tools (Shih \& Tsai, 2017), social networks (Burke \& Fedorek, 2017) and educational platforms (Lo, Lie, \& Hew, 2018) has a fundamental role in improving the teachinglearning conditions.

In a flipped classroom, students consult the videos and digital readings at home in order to review the contents of the courses (Burke \& Fedorek, 2017; Burgoyne \& Eaton, 2018; Chen, Yang, \& Hsiao, 2016). Likewise, teachers organize new collaborative activities in order to discuss, reflect and exchange ideas inside and outside the classroom (Chen, 2016; Shih, \& Tsai, 2017; Zahrani, 2015).

In particular, this research proposes the consultation of the YouTube videos before the class, performance of the collaborative exercises and use of the spreadsheet to check the results during the class and performance of the laboratory practices through the spreadsheet after the class. Therefore, this mixed research analyzes the use of flipped classroom in the teaching-learning process on statistics considering data science and machine learning (linear regression). The research questions are:

- What is the impact of the flipped classroom in the teaching-learning process on statistics?

- How does the participation of the students before, during and after the class (flipped classroom) influence the assimilation of knowledge and development of mathematical skills about the frequencies and measures of central tendency?

- What are the predictive models about the use of flipped classroom in the teaching-learning process on statistics?

- What are the students' perceptions about the use of the flipped classroom in the teaching-learning process? 


\section{Flipped classroom}

During the 21st century, flipped classroom modifies the role, functions and activities of the teachers and students during the educational process (Shih \& Tsai, 2017; Sun, 2017). In fact, this pedagogical model proposes that teachers use class time to organize and realize creative and dynamic activities (Burke \& Fedorek, 2017; Ortiz-Colon, Muñoz-Galiano, \& Colmenero-Ruiz, 2017).

Flipped classroom promotes the use of ICTs in the educational field to modify the traditional process of teaching and learning (Burgoyne \& Eaton, 2018; Ortiz-Colon, Muñoz-Galiano, \& Colmenero-Ruiz, 2017). For example, Lo, Lie and Hew (2018) propose the incorporation of the audiovisual contents and online questionnaires in the school activities. The benefits of this pedagogical model are related to the creation of a pleasant atmosphere for learning and flexibility of time and space to carry out the activities (Ortiz-Colon, Muñoz-Galiano, \& Colmenero-Ruiz, 2017).

Before the face-to-face sessions, students use the educational platforms, digital resources and multimedia products in order to achieve the autonomous learning (Burke \& Fedorek, 2017; Chen, 2016). In the classroom, students and teachers perform active strategies such as discussing, debating and solving problems (Hall \& DuFrene, 2015; Sun, 2017). After the class, students review the digital resources and materials of the course at home (Shih \& Tsai, 2017).

\subsection{Use of flipped classroom in the educational field}

Various authors (e.g., Blau \& Shamir, 2017; Chen, Wang, Kinshuk, \& Chen, 2014; Lo, Lie, \& Hew, 2018; Wang, 2017) have used flipped classroom to improve the teachinglearning process. For example, this pedagogical model facilitates the development of mathematical skills (Lo, Lie, \& Hew, 2018).

In the field of mathematics, Lo, Lie and Hew (2018) implemented flipped classroom through the consultation of the videos and realization of the online questionnaires before the face-to-face session. Also, the discussion among the participants of the educational process and resolution of the exercises is carried out in the classroom with the purpose of promoting the participation of the students (Lo, Lie, \& Hew, 2018).

A flipped classroom allows creating new spaces for learning and teaching (Blau \& Shamir, 2017; Wang, 2017). For example, Chen, Wang, Kinshuk and Chen (2014) 
propose the consultation of the videos and digital readings at home and realization of the online questionnaires and discussion forums in the classroom.

Universities are using a flipped classroom to facilitate the assimilation of knowledge and develop the skills of the students (Blau \& Shamir, 2017; Wang, 2017). At the Israel University, the students consult the lectures, digital presentations and videos at home. In the classroom, these students acquire an active role through discussion and collaborative work (Blau \& Shamir, 2017).

Teachers use flipped classroom to improve the quality of the educational process and perform creative activities inside and outside the classroom (Liu, 2019). For example, the students of architecture reviewed the videos at home and used various technological applications such as Socrative, Sticky note and PadLet in the classroom (Liu, 2019).

Wang (2017) explains that flipped classroom was used at the Taiwan University to improve the teaching-learning conditions, that is, the students consult the videos and digital files on the Moodle platform before the class, participate in the discussion forums during the class and solve the exams in Moodle after the class.

Finally, the flipped classroom is a pedagogical model that allows updating the school activities (Blau \& Shamir, 2017; Wang, 2017), promoting the participation of the students (Burke \& Fedorek, 2017; Lo, Lie, \& Hew, 2018) and improving the teaching-learning conditions (Shih \& Tsai, 2017; Wang, 2017) through the use of the technological tools.

\section{Methodology}

The objective of this mixed research is to analyze the impact of the flipped classroom in the teaching-learning process on statistics considering data science and machine learning (linear regression).

A flipped classroom allows the creation of new school activities inside and outside the classroom (Craft \& Linask, 2020; Morin, Tamberelli, \& Buhagiar, 2020). Therefore, the particular objectives of this research are (1) analyze the impact about the participation of the students before the class in the assimilation of knowledge through the consultation of the YouTube videos (2) analyze the impact about the participation of the students before the class in the development of mathematical skills through the consultation of the YouTube videos (3) analyze the impact about the participation of the students during the class in the assimilation of knowledge through the performance of the collaborative exercises and use of the spreadsheet (4) analyze 
the impact about the participation of the students during the class in the development of mathematical skills through the performance of the collaborative exercises and use of the spreadsheet (5) analyze the impact about the participation of the students after the class in the assimilation of knowledge through the performance of the laboratory practices (6) analyze the impact about the participation of the students after the class in the development of mathematical skills through the performance of the laboratory practices (7) identify the predictive models on the use of flipped classroom during the educational process of statistics and (8) analyze the students' perceptions about the use of flipped classroom.

\subsection{Participants}

The sample is composed of 61 students of the Statistical Instrumentation for Business course (33 men and 28 women) who completed the second semester of the careers in Administration ( $n=9,14.75 \%)$, Accounting ( $n=15,24.59 \%)$, Commerce $(n=19$, $31.15 \%)$, Computing $(\mathrm{n}=2,3.28 \%)$ and Marketing $(\mathrm{n}=16,26.23 \%)$ during the 2018 school year. The average age of the participants is 18.81 years.

\subsection{Procedure}

First, the teacher of the Statistical Instrumentation for Business course identified the technological tools that allow transforming the functions of the students during the Introduction to statistics Unit. In particular, this research proposes the consultation of the YouTube videos before the class, performance of the collaborative exercises and use of the spreadsheet to check the results during the class and performance of the laboratory practices through the spreadsheet after the class. In fact, flipped classroom allowed the organization of 3 sessions about the topics of Frequency, Mean, Standard deviation and Variance (See Table 1). 
Table 1. Activities in the Introduction to statistics Unit

\begin{tabular}{|c|c|c|c|c|c|}
\hline No. & Topic & Objective & Before the class & After the class & During the class \\
\hline 1 & Frequency & $\begin{array}{l}\text { Understand, analyze } \\
\text { and apply the } \\
\text { concepts of the } \\
\text { frequency, relative } \\
\text { frequency and } \\
\text { percentage frequency }\end{array}$ & $\begin{array}{l}\text { Consult the } \\
\text { YouTube videos } \\
\text { on the } \\
\text { frequency and } \\
\text { use of the } \\
\text { formulas in the } \\
\text { spreadsheet }\end{array}$ & $\begin{array}{l}\text { Solve the exercises } \\
\text { on the frequency } \\
\text { collaboratively and } \\
\text { check the results } \\
\text { through the } \\
\text { spreadsheet }\end{array}$ & $\begin{array}{l}\text { Perform the } \\
\text { laboratory } \\
\text { practice on the } \\
\text { frequency } \\
\text { through the } \\
\text { spreadsheet }\end{array}$ \\
\hline 2 & $\begin{array}{l}\text { Mean and } \\
\text { Standard } \\
\text { deviation }\end{array}$ & $\begin{array}{l}\text { Understand, analyze } \\
\text { and apply the } \\
\text { concepts of the mean } \\
\text { and standard } \\
\text { deviation for the } \\
\text { sample and } \\
\text { population }\end{array}$ & $\begin{array}{l}\text { Consult the } \\
\text { YouTube videos } \\
\text { on the mean, } \\
\text { standard } \\
\text { deviation and } \\
\text { use of the } \\
\text { formulas in the } \\
\text { spreadsheet }\end{array}$ & $\begin{array}{l}\text { Solve the exercises } \\
\text { on the mean and } \\
\text { standard deviation } \\
\text { collaboratively and } \\
\text { check the results } \\
\text { through the } \\
\text { spreadsheet }\end{array}$ & $\begin{array}{l}\text { Perform the } \\
\text { laboratory } \\
\text { practice on the } \\
\text { mean and } \\
\text { standard } \\
\text { deviation } \\
\text { through the } \\
\text { spreadsheet }\end{array}$ \\
\hline 3 & Variance & $\begin{array}{l}\text { Understand, analyze } \\
\text { and apply the } \\
\text { concepts of the } \\
\text { variance for the } \\
\text { sample and } \\
\text { population }\end{array}$ & $\begin{array}{l}\text { Consult the } \\
\text { YouTube videos } \\
\text { on the variance } \\
\text { and use of the } \\
\text { formulas in the } \\
\text { spreadsheet }\end{array}$ & $\begin{array}{l}\text { Solve the exercises } \\
\text { on the variance } \\
\text { collaboratively and } \\
\text { check the results } \\
\text { through the } \\
\text { spreadsheet }\end{array}$ & $\begin{array}{l}\text { Perform the } \\
\text { laboratory } \\
\text { practice on the } \\
\text { variance through } \\
\text { the spreadsheet }\end{array}$ \\
\hline
\end{tabular}

Figure 1 shows the technological acceptance model used to analyze the impact of a flipped classroom during the teaching-learning process.

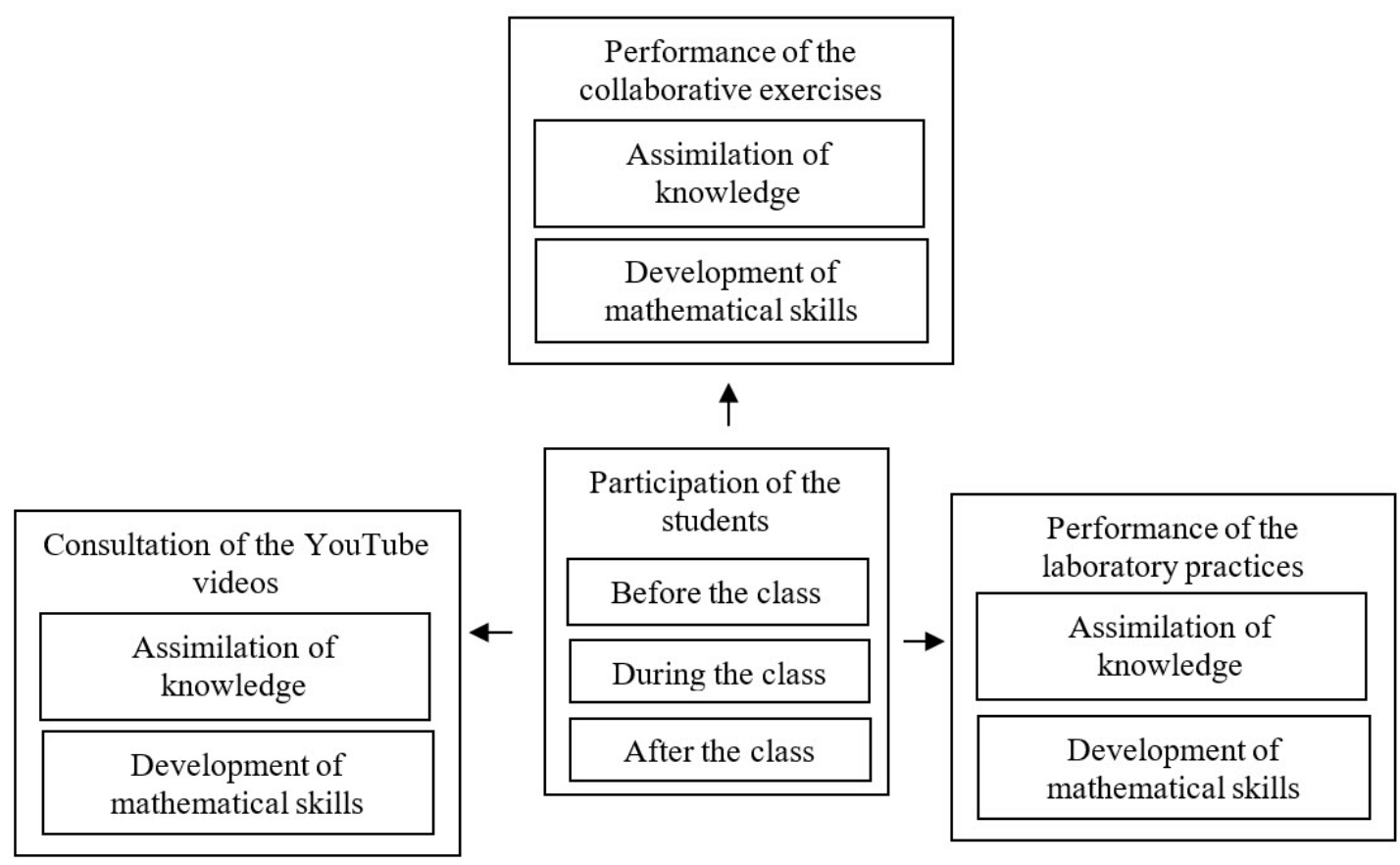

Figure 1. Technological acceptance model. 
The review of videos at home facilitates the learning process during the flipped classroom (Krouss \& Lesseig, 2020; Turra et al., 2019; Zainuddin \& Perera, 2019). Therefore, the research hypotheses related to the activities before the face-to-face session are:

- Hypothesis 1 (H1): The participation of the students before the class positively influences the assimilation of knowledge through the consultation of the YouTube videos

- Hypothesis 2 (H2): The participation of the students before the class positively influences the development of mathematical skills through the consultation of the YouTube videos

The use of ICTs and collaborative work in the classroom improve the teachinglearning conditions during flipped classroom (Chan, Lam, \& Ng, 2020; Craft \& Linask, 2020; Morin, Tamberelli, \& Buhagiar, 2020). Therefore, the research hypotheses related to the activities during the face-to-face session are:

- Hypothesis $3\left(\mathrm{H}_{3}\right)$ : The participation of the students during the class positively influences the assimilation of knowledge through the performance of the collaborative exercises and use of the spreadsheet

- Hypothesis $4\left(\mathrm{H}_{4}\right)$ : The participation of the students during the class positively influences the development of mathematical skills through the performance of the collaborative exercises and use of the spreadsheet

In a flipped classroom, students actively participate after the class through the realization of creative activities (Craft \& Linask, 2020; Krouss \& Lesseig, 2020; Morin, Tamberelli, \& Buhagiar, 2020). Therefore, the research hypotheses related to the activities after the face-to-face session are:

- Hypothesis $5\left(\mathrm{H}_{5}\right)$ : The participation of the students after the class positively influences the assimilation of knowledge through the performance of the laboratory practices

- Hypothesis 6 (H6): The participation of the students after the class positively influences the development of mathematical skills through the performance of the laboratory practices 
The decision tree technique (data science) identifies the following predictive models about the use of flipped classroom in the teaching-learning process on statistics:

- Predictive Model 1 (PM1) on the assimilation of knowledge and participation of the students before the class through the consultation of the YouTube videos

- Predictive Model 2 (PM2) on the development of mathematical skills and participation of the students before the class through the consultation of the YouTube videos

- Predictive Model 3 ( $\left.\mathrm{PM}_{3}\right)$ on the assimilation of knowledge and participation of the students during the class through the performance of the collaborative exercises and use of the spreadsheet

- Predictive Model $4\left(\mathrm{PM}_{4}\right)$ on the development of mathematical skills and participation of the students during the class through the performance of the collaborative exercises and use of the spreadsheet

- Predictive Model 5 ( $\mathrm{PM}_{5}$ ) on the assimilation of knowledge and participation of the students after the class through the performance of the laboratory practices

- Predictive Model 6 (PM6) on the development of mathematical skills and participation of the students after the class through the performance of the laboratory practices

\subsection{Data analysis}

The Rapidminer tool allows the calculation of machine learning (linear regression) to evaluate the research hypotheses on the use of flipped classroom in the educational field and construction of the predictive models through the decision tree technique.

Machine learning allows evaluating the research hypotheses on the use of flipped classroom through the training and evaluation sections. The training section with $70 \%$ $(n=43), 80 \%(n=49)$ and $90 \%(n=55)$ of the sample allows calculating the linear regressions on the use of flipped classroom and evaluation section with $30 \%(n=18)$, $20 \%(n=12)$ and $10 \%(n=6)$ of the sample allows identifying the accuracy of these linear regressions.

For example, Salas-Rueda, Salas-Rueda and Salas-Rueda (2020) used machine learning to analyze the impact on the use of a digital game in the field of statistics considering different sample sizes.

Likewise, the Rapidminer tool allows the construction of predictive models on the consultation of the YouTube videos before the class, the performance of the 
collaborative exercises and use of the spreadsheet during the class and performance of the laboratory practices through the spreadsheet after the class. Information about the student's profile and flipped classroom is used to build 6 predictive models through the decision tree technique.

\subsection{Data collection}

At the end of Introduction to statistics unit (February 2018), the measuring instrument (questionnaire) was applied to collect the information about the use of flipped classroom (see Table 2).

Table 2. Questionnaire on the use of flipped classroom

\begin{tabular}{|c|c|c|c|c|c|c|}
\hline No. & Variable & Dimension & Question & Answer & $\mathbf{n}$ & $\%$ \\
\hline \multirow{13}{*}{1} & \multirow{13}{*}{$\begin{array}{l}\text { Profile of the } \\
\text { students }\end{array}$} & \multirow{5}{*}{ Career } & \multirow{5}{*}{ 1. Indicate your career } & Administration & 9 & $14.75 \%$ \\
\hline & & & & Commerce & 19 & $31.15 \%$ \\
\hline & & & & Accountancy & 15 & $24.59 \%$ \\
\hline & & & & Marketing & 16 & $26.23 \%$ \\
\hline & & & & Computing & 2 & $3.28 \%$ \\
\hline & & \multirow{6}{*}{ Age } & \multirow{6}{*}{ 2. Indicate your age } & & & \\
\hline & & & & 18 years & 25 & $40.98 \%$ \\
\hline & & & & 19 years & 25 & $40.98 \%$ \\
\hline & & & & 20 years & 9 & $14.75 \%$ \\
\hline & & & & 21 years & 1 & $1.64 \%$ \\
\hline & & & & 22 years & 1 & $1.64 \%$ \\
\hline & & \multirow[t]{2}{*}{ Sex } & \multirow[t]{2}{*}{ 3. Indicate your sex } & Man & 33 & $54.10 \%$ \\
\hline & & & & Woman & 28 & $45.90 \%$ \\
\hline \multirow{17}{*}{2} & \multirow{17}{*}{$\begin{array}{l}\text { Flipped } \\
\text { classroom }\end{array}$} & \multirow{15}{*}{$\begin{array}{l}\text { Activities before } \\
\text { the face-to-face } \\
\text { session }\end{array}$} & \multirow{5}{*}{$\begin{array}{l}\text { 4. The activities before the class } \\
\text { improve the participation of the } \\
\text { students during the learning } \\
\text { process }\end{array}$} & Too much (1) & 32 & $52.46 \%$ \\
\hline & & & & Much (2) & 26 & $42.62 \%$ \\
\hline & & & & Some (3) & 3 & $4.92 \%$ \\
\hline & & & & Little (4) & 0 & $0.00 \%$ \\
\hline & & & & Too little (5) & 0 & $0.00 \%$ \\
\hline & & & \multirow{5}{*}{$\begin{array}{l}\text { 5. The consultation of the YouTube } \\
\text { videos improves the assimilation of } \\
\text { knowledge }\end{array}$} & Too much (1) & 35 & $57.38 \%$ \\
\hline & & & & Much (2) & 24 & $39.34 \%$ \\
\hline & & & & Some (3) & 2 & $3.28 \%$ \\
\hline & & & & Little (4) & 0 & $0.00 \%$ \\
\hline & & & & Too little (5) & 0 & $0.00 \%$ \\
\hline & & & \multirow{5}{*}{$\begin{array}{l}\text { 6. The consultation of YouTube } \\
\text { videos improves the development } \\
\text { of mathematical skills }\end{array}$} & Too much (1) & 29 & $47.54 \%$ \\
\hline & & & & Much (2) & 29 & $47.54 \%$ \\
\hline & & & & Some (3) & 3 & $4.92 \%$ \\
\hline & & & & Little (4) & 0 & $0.00 \%$ \\
\hline & & & & Too little (5) & 0 & $0.00 \%$ \\
\hline & & & \multirow{2}{*}{$\begin{array}{l}\text { 7. The activities during the class } \\
\text { improve the participation of the }\end{array}$} & Too much (1) & 45 & $73.77 \%$ \\
\hline & & & & Much (2) & 16 & $26.23 \%$ \\
\hline
\end{tabular}


Activities during the face-to-face session

Activities after the face-to-face session students during the learning process

8. The performance of the collaborative exercises and use of the spreadsheet improve the assimilation of knowledge

9. The performance of the collaborative exercises and use of the spreadsheet improve the development of mathematical skills

\begin{tabular}{lll} 
Some (3) & 0 & $0.00 \%$ \\
\hline Little (4) & 0 & $0.00 \%$ \\
\hline Too little (5) & 0 & $0.00 \%$
\end{tabular}

\begin{tabular}{lll}
\hline Too much (1) & 42 & $68.85 \%$ \\
\hline Much (2) & 19 & $31.15 \%$ \\
\hline Some (3) & 0 & $0.00 \%$ \\
\hline Little (4) & 0 & $0.00 \%$ \\
\hline Too little (5) & 0 & $0.00 \%$ \\
\hline
\end{tabular}

\begin{tabular}{lll}
\hline Too much (1) & 43 & $70.49 \%$ \\
\hline Much (2) & 16 & $26.23 \%$ \\
\hline Some (3) & 2 & $3.28 \%$ \\
\hline Little (4) & 0 & $0.00 \%$ \\
\hline Too little (5) & 0 & $0.00 \%$ \\
\hline
\end{tabular}

10. The activities after the class improve the participation of the students during the learning process

\begin{tabular}{lll}
\hline Too much (1) & 35 & $57.38 \%$ \\
\hline Much (2) & 25 & $40.98 \%$ \\
\hline Some (3) & 1 & $1.64 \%$ \\
\hline Little (4) & 0 & $0.00 \%$ \\
\hline Too little (5) & 0 & $0.00 \%$ \\
\hline
\end{tabular}

11. The performance of the laboratory practices through the spreadsheet improves the assimilation of knowledge

\begin{tabular}{lll}
\hline Too much (1) & 32 & $52.46 \%$ \\
\hline Much (2) & 29 & $47.54 \%$ \\
\hline Some (3) & 0 & $0.00 \%$ \\
\hline Little (4) & 0 & $0.00 \%$ \\
\hline Too little (5) & 0 & $0.00 \%$
\end{tabular}

12. The performance of the laboratory practices through the spreadsheet improves the development of mathematical skills

\begin{tabular}{llll}
$\begin{array}{l}\text { Educational } \\
\text { process }\end{array}$ & $\begin{array}{l}\text { 13. Does the flipped classroom } \\
\text { improve the educational process? }\end{array}$ & Open & - \\
\hline Motivation & $\begin{array}{l}\text { 14. Does the flipped classroom } \\
\text { increase the motivation during the } \\
\text { teaching-learning process? }\end{array}$ & Open & - \\
\hline Benefits & $\begin{array}{l}\text { 15. What are the benefits of the } \\
\text { flipped classroom? }\end{array}$ & Open & - \\
\hline Satisfaction & $\begin{array}{l}\text { 16. Are you satisfied to do the } \\
\text { activities before, during and after } \\
\text { the class? }\end{array}$ & Open & - \\
\hline Utility & $\begin{array}{l}\text { 17. Is the flipped classroom useful } \\
\text { in the educational context? }\end{array}$ & Open & - \\
\hline Skills & $\begin{array}{l}\text { 18. Does the flipped classroom } \\
\text { facilitate the development of } \\
\text { mathematical skills? }\end{array}$ & Open & - \\
\hline Innovation & $\begin{array}{l}\text { 19. Does the flipped classroom } \\
\text { allow innovating the school } \\
\text { activities? }\end{array}$ & $\begin{array}{l}\text { 20. Does the flipped classroom } \\
\text { favor the participation of the } \\
\text { students during the learning } \\
\text { process? }\end{array}$ & Open \\
\hline Participation of \\
the students
\end{tabular}


To validate the measuring instrument, the questionnaire must present the values of Cronbach's Alpha (> 0.700), Load Factor ( $>0.500$ ) and Composite Reliability ( $>$ 0.700). Table 3 shows that the questionnaire on the use of flipped classroom in the educational field meets these criteria.

Table 3. Validation of the questionnaire

\begin{tabular}{|c|c|c|c|c|c|c|}
\hline No. & Variable & Dimension & $\begin{array}{l}\text { Load } \\
\text { factor }\end{array}$ & $\begin{array}{l}\text { Cronbach's } \\
\text { alpha }\end{array}$ & $\begin{array}{l}\text { Average } \\
\text { Variance } \\
\text { Extracted }\end{array}$ & $\begin{array}{l}\text { Composite } \\
\text { Reliability }\end{array}$ \\
\hline 1 & $\begin{array}{l}\text { Activities } \\
\text { before the } \\
\text { face-to-face } \\
\text { session }\end{array}$ & $\begin{array}{l}\text { Participation of the } \\
\text { students } \\
\text { Assimilation of } \\
\text { knowledge } \\
\text { Development of } \\
\text { mathematical skills }\end{array}$ & $\begin{array}{l}0.827 \\
0.853 \\
0.911\end{array}$ & 0.829 & 0.747 & 0.898 \\
\hline 2 & $\begin{array}{l}\text { Activities } \\
\text { during the } \\
\text { face-to-face } \\
\text { session }\end{array}$ & $\begin{array}{l}\text { Participation of the } \\
\text { students } \\
\text { Assimilation of } \\
\text { knowledge } \\
\text { Development of } \\
\text { mathematical skills }\end{array}$ & $\begin{array}{l}0.876 \\
0.918 \\
0.870\end{array}$ & 0.861 & 0.789 & 0.918 \\
\hline 3 & $\begin{array}{l}\text { Activities after } \\
\text { the face-to- } \\
\text { face session }\end{array}$ & $\begin{array}{l}\text { Participation of the } \\
\text { students } \\
\text { Assimilation of } \\
\text { knowledge } \\
\text { Development of } \\
\text { mathematical skills }\end{array}$ & $\begin{array}{l}0.849 \\
0.898 \\
0.897\end{array}$ & 0.856 & 0.777 & 0.912 \\
\hline
\end{tabular}

\section{Results}

The results of machine learning with $70 \%, 80 \%$ and $90 \%$ training indicate that the participation of the students before, during and after the class positively influences the assimilation of knowledge and development of mathematical skills (See Table 4). 
Table 4. Results of machine learning (linear regression)

\begin{tabular}{lllll}
\hline Hypothesis & Training & Linear regression & Conclusion & Square error \\
\hline H1: Participation of the & $70 \%$ & $y=0.482 x+0.863$ & Accepted: 0.482 & 0.165 \\
students before the class $\rightarrow$ & $80 \%$ & $y=0.510 x+0.811$ & Accepted: 0.510 & 0.163 \\
assimilation of knowledge & $90 \%$ & $y=0.530 x+0.773$ & Accepted: 0.530 & 0.171 \\
\hline H2: Participation of the & $70 \%$ & $y=0.618 x+0.658$ & Accepted: 0.618 & 0.148 \\
$\begin{array}{l}\text { students before the class } \rightarrow \\
\text { development of mathematical }\end{array}$ & $80 \%$ & $y=0.634 x+0.594$ & Accepted: 0.634 & 0.131 \\
skills & $90 \%$ & $y=0.666 x+0.533$ & Accepted: 0.666 & 0.232 \\
\hline H3: Participation of the & $70 \%$ & $y=0.894 x+0.140$ & Accepted: 0.894 & 0.256 \\
$\begin{array}{l}\text { students during the class } \rightarrow \\
\text { assimilation of knowledge }\end{array}$ & $80 \%$ & $y=0.845 x+0.243$ & Accepted: 0.845 & 0.217 \\
\hline $\begin{array}{l}\text { H4: Participation of the } \\
\text { students during the class } \rightarrow\end{array}$ & $70 \%$ & $y=0.772 x+0.330$ & Accepted: 0.772 & 0.142 \\
$\begin{array}{l}\text { development of mathematical } \\
\text { skills }\end{array}$ & $90 \%$ & $y=0.756 x+0.416$ & Accepted: 0.756 & 0.110 \\
\hline $\begin{array}{l}\text { H5: Participation of the } \\
\text { students after the class } \rightarrow\end{array}$ & $70 \%$ & $y=0.758 x+0.419$ & Accepted: 0.758 & 0.101 \\
assimilation of knowledge & $80 \%$ & $y=0.721 x+0.432$ & Accepted: 0.721 & 0.023 \\
\hline $\begin{array}{l}\text { H6: Participation of the } \\
\text { students after the class } \rightarrow\end{array}$ & $70 \%$ & $y=0.550 x+0.712$ & Accepted: 0.550 & 0.106 \\
$\begin{array}{l}\text { development of mathematical } \\
\text { skills }\end{array}$ & $90 \%$ & $y=0.537 x+0.687$ & Accepted: 0.557 & 0.056 \\
\hline
\end{tabular}

\subsection{Before the class}

The activities before the class improve too much $(\mathrm{n}=32,52.46 \%)$, much $(\mathrm{n}=26$, 42.62\%) and some $(n=3,4.92 \%)$ the participation of the students during the learning process. In addition, the consultation of YouTube videos improves too much $(\mathrm{n}=35$, $57.38 \%)$, much $(n=24,39.34 \%)$ and some $(n=2,3.28 \%)$ the assimilation of knowledge (See Table 2).

The results of machine learning with 70\% (0.482), 80\% (0.510) and 90\% (0.530) of training indicate that $\mathrm{H} 1$ is accepted (See Table 4). Therefore, the participation of the students before the class positively influences the assimilation of knowledge through the consultation of the YouTube videos.

Table 5 shows the conditions of PM1. For example, if the student considers that the activities before the class improve much the participation of the students during the learning process, takes the career of Commerce, has an age $>18.5$ years and is a man then the consultation of YouTube videos improves much the assimilation of knowledge. 
Table 5. Conditions of the PM1

\begin{tabular}{|c|c|c|c|c|c|}
\hline No. & $\begin{array}{c}\text { Activities before the } \\
\text { class } \rightarrow \text { participation of } \\
\text { the students }\end{array}$ & Sex & Career & Age & $\begin{array}{c}\text { Consultation of the } \\
\text { YouTube videos } \rightarrow \\
\text { assimilation of knowledge }\end{array}$ \\
\hline 1 & Too much & - & - & - & Too much \\
\hline 2 & Much & - & Administration & - & Much \\
\hline 3 & Much & Man & Commerce & $>18.5$ years & Much \\
\hline 4 & Much & Woman & Commerce & $>18.5$ years & Too much \\
\hline 5 & Much & - & Commerce & $\leq 18.5$ years & Much \\
\hline 6 & Much & Man & Accounting & - & Too much \\
\hline 7 & Much & Woman & Accounting & - & Much \\
\hline 8 & Much & - & Marketing & - & Too much \\
\hline 9 & Some & Man & - & - & Much \\
\hline 10 & Some & Woman & - & - & Too much \\
\hline
\end{tabular}

PM1 has an accuracy of $88.52 \%$ and presents 10 conditions on the consultation of the YouTube videos and assimilation of knowledge (See Table 5). For example, if the student considers that the activities before the class improve much the participation of the students during the learning process and takes the career of Marketing then the consultation of the YouTube videos improves too much the assimilation of knowledge.

The consultation of the YouTube videos improves too much ( $\mathrm{n}=29,47.54 \%)$, much $(\mathrm{n}=29,47.54 \%)$ and some $(\mathrm{n}=3,4.92 \%)$ the development of mathematical skills (see Table 2). Likewise, the results of machine learning with 70\% (0.618), 80\% (0.634) and 90\% (0.666) of training indicate that H2 is accepted (See Table 4). Therefore, the participation of the students before the class positively influences the development of mathematical skills through the consultation of YouTube videos.

Table 6 shows the conditions of the PM2. For example, if the student considers that the activities before the class improve much the participation of the students during the learning process and takes the career of Marketing, then the consultation of the YouTube videos improves too much the development of mathematical skills. 
Table 6. Conditions of the PM2

\begin{tabular}{cccccc}
\hline No. & $\begin{array}{c}\text { Activities before the } \\
\text { class } \rightarrow \text { participation } \\
\text { of the students }\end{array}$ & Sex & Career & Age & $\begin{array}{c}\text { Consultation of the YouTube } \\
\text { videos } \rightarrow \text { development of } \\
\text { mathematical skills }\end{array}$ \\
\hline 1 & Too much & - & - & - & Too much \\
2 & Much & - & Administration & - & Much \\
3 & Much & Man & Commerce & - & Much \\
4 & Much & Woman & Commerce & $>18.5$ years & Too much \\
5 & Much & Woman & Commerce & $\leq 18.5$ years & Much \\
6 & Much & Man & Accounting & $>18.5$ years & Some \\
7 & Much & Woman & Accounting & $>18.5$ years & Much \\
8 & Much & - & Accounting & $\leq 18.5$ years & Too much \\
9 & Much & - & Marketing & - & Too much \\
10 & Some & - & Commerce & - & Much \\
11 & Some & - & Accountancy & - & Some \\
12 & Some & - & Marketing & - & Much \\
\hline
\end{tabular}

$\mathrm{PM} 2$ has an accuracy of $81.97 \%$ and presents 12 conditions on the consultation of the YouTube videos and the development of mathematical skills (See Table 6). For example, if the student considers that the activities before the class improve much the participation of the students during the learning process and takes the career of Administration then the consultation of the YouTube videos improves much the development of mathematical skills.

\subsection{During the class}

The activities during the class improve too much $(n=45,73.77 \%)$ and much $(n=16$, 26.23\%) the participation of the students during the learning process (See Table 2). Also, the performance of the collaborative exercises and use of the spreadsheet improve too much $(n=42,68.85 \%)$ and much $(n=19,31.15 \%)$ the assimilation of knowledge.

The results of machine learning with 70\% (0.894), 80\% (0.845) and 90\% (0.772) of training indicate that $\mathrm{H}_{3}$ is accepted (See Table 4). Therefore, the participation of the students during the class positively influences the assimilation of knowledge through the performance of the collaborative exercises and use of the spreadsheet.

Table 7 shows the conditions of PM3. For example, if the student considers that the activities during the class improve much the participation of the students during the learning process and takes the career of Administration then the performance of the collaborative exercises and use of the spreadsheet improve much the assimilation of knowledge. 
Table 7. Conditions of the PM3

\begin{tabular}{cccccc}
\hline $\begin{array}{c}\text { No. } \\
\text { Activities during the } \\
\text { class } \rightarrow \text { participation } \\
\text { of the students }\end{array}$ & Sex & Career & Age & $\begin{array}{c}\text { Performance of the collaborative } \\
\text { exercises and use of the } \\
\text { spreadsheet } \rightarrow \text { assimilation of } \\
\text { knowledge }\end{array}$ \\
\hline 1 & Too much & - & - & - & Too much \\
2 & Much & - & Administration & - & Much \\
3 & Much & - & Commerce & - & Much \\
4 & Much & Man & Accounting & - & Too much \\
5 & Much & Woman & Accounting & - & Much \\
6 & Much & Man & Marketing & - & Much \\
7 & Much & Woman & Marketing & - & Too much \\
\hline
\end{tabular}

PM3 has an accuracy of $90.16 \%$ and presents 7 conditions on the performance of the collaborative exercises, use of the spreadsheet and assimilation of knowledge (See Table 7). For example, if the student considers that the activities during the class improve much the participation of the students during the learning process and takes the career of Commerce then the performance of the collaborative exercises and use of the spreadsheet improve much the assimilation of knowledge.

The performance of the collaborative exercises and use of the spreadsheet improve too much ( $\mathrm{n}=43,70.49 \%)$, much $(\mathrm{n}=16,26.23 \%)$ and some $(\mathrm{n}=2,3.28 \%)$ the development of mathematical skills (See Table 2). Likewise, the results of machine learning with 70\% (0.756), 80\% (0.758) and 90\% (0.721) of training indicate that $\mathrm{H}_{4}$ is accepted (See Table 4). Therefore, the participation of the students during the class positively influences the development of mathematical skills through the performance of the collaborative exercises and the use of the spreadsheet.

Table 8 shows the conditions of the PM4. For example, if the student considers that the activities during the class improve much the participation of the students during the learning process and takes the career of Marketing then the performance of the collaborative exercises and use of the spreadsheet improve too much the development of mathematical skills. 
Table 8. Conditions of the PM4

\begin{tabular}{cccccc}
\hline No. $\begin{array}{c}\text { Activities during } \\
\text { the class } \rightarrow \\
\text { participation of the } \\
\text { students }\end{array}$ & Sex & Career & Age & $\begin{array}{c}\text { Performance of the collaborative } \\
\text { exercises and use of the } \\
\text { spreadsheet } \rightarrow \text { development of } \\
\text { mathematical skills }\end{array}$ \\
\hline 1 & Too much & - & Marketing & - & Too much \\
2 & Too much & - & Computing & - & Too much \\
3 & Too much & - & Commerce & - & Too much \\
4 & Too much & - & Accounting & - & Too much \\
5 & Too much & - & Administration & $\leq 18.5$ & years \\
6 & Too much & Man & Administration & $>18.5$ & Too much \\
7 & Too much & Woman & Administration & $>18.5$ & Some \\
8 & Much & - & Administration & - & Too much \\
9 & Much & - & Commerce & - & Much \\
10 & Much & - & Marketing & - & Much \\
11 & Much & Man & Accounting & $\leq 18.5$ & Too much \\
12 & Much & Man & Accounting & $>18.5$ & Too much \\
13 & Much & Woman & Accounting & - & Some \\
\hline
\end{tabular}

PM4 has an accuracy of $93.44 \%$ accurate and presents 13 conditions on the performance of the collaborative exercises, use of the spreadsheet and development of mathematical skills (See Table 8). For example, if the student considers that the activities during the class improve much the participation of the students during the learning process and takes the career of Commerce then the performance of the collaborative exercises and use of the spreadsheet improve much the development of mathematical skills.

\subsection{After the class}

The activities after the class improve too much $(\mathrm{n}=35,57.38 \%)$, much $(\mathrm{n}=25$, 40.98\%) and some ( $\mathrm{n}=1,1.64 \%)$ the participation of the students during the learning process (See Table 2). Also, the performance of the laboratory practices through the spreadsheet improves too much $(\mathrm{n}=32,52.46 \%)$ and much $(\mathrm{n}=29,47.54 \%)$ the assimilation of knowledge.

The results of machine learning with 70\% (0.496), 80\% (0.550) and 90\% (0.557) of training indicate that $\mathrm{H}_{5}$ is accepted (See Table 4 ). Therefore, the participation of 
the students after the class positively influences the assimilation of knowledge through the performance of the laboratory practices.

Table 9 shows the conditions of the PM5. For example, if the student considers that the activities after the class improve too much the participation of the students during the learning process and takes the career of Marketing then the performance of the laboratory practices through the spreadsheet improves too much the assimilation of knowledge.

Table 9. Conditions of the PM5

\begin{tabular}{|c|c|c|c|c|c|}
\hline No. & $\begin{array}{l}\text { Activities after the } \\
\text { class } \rightarrow \text { participation } \\
\text { of the students }\end{array}$ & Sex & Career & Age & $\begin{array}{c}\text { Performance of the } \\
\text { laboratory practices } \rightarrow \\
\text { assimilation of knowledge }\end{array}$ \\
\hline 1 & Too much & - & Marketing & - & Too much \\
\hline 2 & Too much & - & Computing & - & Too much \\
\hline 3 & Too much & - & Accounting & - & Too much \\
\hline 4 & Too much & Woman & Commerce & - & Too much \\
\hline 5 & Too much & Man & Commerce & $>18.5$ years & Too much \\
\hline 6 & Too much & Man & Commerce & $\leq 18.5$ years & Much \\
\hline 7 & Too much & Woman & Administration & - & Too much \\
\hline 8 & Too much & Man & Administration & > 18.5 years & Much \\
\hline 9 & Too much & Man & Administration & $\leq 18.5$ years & Too much \\
\hline 10 & Much & Man & Administration & > 18.5 years & Much \\
\hline 11 & Much & Man & Administration & $\leq 18.5$ years & Too much \\
\hline 12 & Much & Woman & Administration & - & Much \\
\hline 13 & Much & - & Commerce & - & Much \\
\hline 14 & Much & - & Accounting & $>20$ years & Too much \\
\hline 15 & Much & - & Accounting & $\leq 20$ years & Much \\
\hline 16 & Much & - & Marketing & - & Much \\
\hline 17 & Some & - & - & - & Much \\
\hline
\end{tabular}

$\mathrm{PM}_{5}$ has an accuracy of $88.52 \%$ and presents 17 conditions on the performance of the laboratory practices and assimilation of knowledge (See Table 9). For example, if the student considers that the activities after the class improve much the participation of the students during the learning process and takes the career of Marketing then the performance of laboratory practices through the spreadsheet improves much the assimilation of knowledge.

The activities after the class improve too much $(\mathrm{n}=32,52.46 \%)$ and much $(\mathrm{n}=$ 29, 47.54\%) the participation of the students during the learning process (See Table 2). The results of machine learning with $70 \%(0.532), 80 \%(0.582)$ and 90\% (0.587) of training indicate that $\mathrm{H} 6$ is accepted (See Table 4). Therefore, the participation of 
the students after the class positively influences the development of mathematical skills through the performance of the laboratory practices.

Table 10 shows the conditions of PM6. For example, if the student considers that the activities after the class improve too much the participation of the students during the learning process and takes the career of Commerce then the performance of the laboratory practices through the spreadsheet improves too much the development of mathematical skills.

Table 10. Conditions of PM6

\begin{tabular}{cccccc}
\hline $\begin{array}{c}\text { Activities after the } \\
\text { class } \rightarrow \text { participation } \\
\text { of the students }\end{array}$ & Sex & Career & Age & $\begin{array}{c}\text { Performance of the } \\
\text { laboratory practices } \rightarrow \\
\text { development of } \\
\text { mathematical skills }\end{array}$ \\
\hline 1 & Too much & - & Marketing & - & Too much \\
2 & Too much & - & Computing & - & Too much \\
3 & Too much & - & Commerce & - & Too much \\
4 & Too much & - & Accounting & - & Too much \\
5 & Too much & Woman & Administration & - & Too much \\
6 & Too much & Man & Administration & $>18.5$ years & Much \\
7 & Too much & Man & Administration & $\leq 18.5$ years & Too much \\
8 & Much & - & - & $\leq 19.5$ years & Much \\
9 & Much & - & Administration & $>19.5$ years & Too much \\
10 & Much & - & Commerce & $>19.5$ years & Much \\
11 & Much & - & Accounting & $>19.5$ years & Too much \\
12 & Much & - & Marketing & $>19.5$ years & Much \\
13 & Some & - & - & - & Much \\
\hline
\end{tabular}

PM6 has an accuracy of $86.89 \%$ and presents 13 conditions on the realization of the laboratory practices and development of mathematical skills (See Table 10). For example, if the student considers that the activities after the class improve too much the participation of the student during the learning process and takes the career of Accounting then the performance of the laboratory practices through the spreadsheet improves too much the development of mathematical skills. 


\subsection{Perceptions of the students}

The flipped classroom allows the construction of new educational spaces that improve the teaching-learning conditions and facilitate the active participation of the students. According to the students of the Statistical Instrumentation for Business course, flipped classroom facilitates the educational process on frequencies and measures of central tendency:

\footnotetext{
"Yes, it helps to understand and review the topics of the class [...]. The videos and spreadsheet facilitate the learning [...]." (Student 10, Woman, 18 years, Accounting).

"Yes, I learn faster with the help of technology [...]. I solve my doubts with the spreadsheet." (Student 28, Man, 19 years, Commerce).

"Yes, because we have more tools to learn [...]. Also, I learn more with the help of my classmate." (Student 35, Woman, 18 years, Commerce).
}

Teachers can create new activities before, during and after the class through the flipped classroom. In fact, the students are motivated to use technology in the teaching-learning process:
"Yes, it's more fun [...] we learn through the technology." (Student 1, Woman, 18 years, Marketing).
"Yes, because it is more interactive [...]. I get the results of the exercises quickly with the spreadsheet." (Student 26, Man, 20 years, Commerce).
"Yes, because they are different ways to learn [...] I really liked using the spreadsheet [...] I learn more and it's not boring." (Student 33, Woman, 18 years, Accounting).

The active participation of the students before, during and after the class improves the assimilation of knowledge and develops the skills. One of the benefits of the flipped classroom in the educational field is the improvement of the learning process:

\footnotetext{
"I learn easier [...] I can see the information at home." (Student 19, Man, 18 years, Administration).

"I use technology, learn and resolve my doubts." (Student 20, Man, 18 years, Marketing).

"Facilitates the learning, helps me for the realization of the homework and prepare for the exam." (Student 25, Man, 21 years, Accounting).
}

The use of the videos and spreadsheet in the school activities improved the teachinglearning process on statistics. In fact, the students of Administration, Accounting, Commerce, Computing and Marketing are satisfied to use flipped classroom: 


\begin{abstract}
"Yes, we learn more and in different ways [...]. For example, I can watch the videos many times [...]." (Student 15, Woman, 20 years, Marketing).

"Yes, because everything is very clear due to the use of these technological tools. [...] with the activities carried out in the class I learn more [...]." (Student 44, Woman, 19 years, Marketing).

"Yes, it is a different way to learn. I verify the results with the spreadsheet [...]. In the classroom, I solve the doubts with my partner." (Student 47, Woman, 18 years, Commerce).
\end{abstract}

Technological advances and pedagogical models such as flipped classroom are changing the behavior and functions of the students and teachers during the educational process. In particular, the students of the Statistical Instrumentation for Business course consider that flipped classroom is useful for the educational context:

\footnotetext{
"Yes, it helps the learning process [...] I verify that my answers are correct with the spreadsheet." (Student 10, Woman, 18 years, Accounting).

"Yes, I learn in various ways [...]. I loved using the formulas in the spreadsheet. It is more practical." (Student 37, Man, 19 years, Accounting).

"Yes, I learn [...] it's interesting to watch the videos before the class, I had never done it." (Student 43, Woman, 20 years, Marketing).
}

Technological tools play a fundamental role during the realization of the learning process inside and outside the classroom. For example, the flipped classroom facilitates the development of mathematical skills in the Statistical Instrumentation for Business course through the spreadsheet:

\footnotetext{
"Yes, because I use the contents in the practical context and check the exercises with the formulas in the spreadsheet." (Student 10, Woman, 18 years, Accounting).

"Yes, because I analyze the exercises with the help of the spreadsheet [...] I apply the knowledge." (Student 11, Woman, 19 years, Commerce).

"Yes, I practice at home what I see in the class [...]. I use the technology to check the results." (Student 32, Woman, 19 years, Administration).
}

In the 21st century, flipped classroom facilitates the organization and creation of creative activities where students are the main actor during the learning process. The students of Administration, Accounting, Commerce, Computing and Marketing think that flipped classroom is an innovative pedagogical model for the educational field:

\footnotetext{
"Innovative and creative." (Student 4, Man, 20 years, Marketing).

"Yes, the videos and use of the spreadsheet are innovative and very useful." (Student 5, Man, 19 years, Marketing).

"Yes, few teachers use it." (Student 32, Woman, 19 years, Administration).
} 
Finally, the flipped classroom fosters the participation of the students during the learning process through the consultation of the YouTube videos, performance of the collaborative exercises and realization of the laboratory practices:

"Yes, the role of the student is more dynamic [...]. I liked doing the activities with my partner." (Student 3, Man, 19 years, Accounting).

"Yes, it is interactive. It is easier to learn and study for the exam [...]." (Student 31, Woman, 18 years, Marketing).

"Yes, it keeps us entertained by using different technological tools." (Student 33, Woman, 18 years, Accounting).

\section{Discussion}

Flipped classroom promotes the modification and updating of traditional educational practices through the use of pedagogical strategies and technology (Burgoyne \& Eaton, 2018; Shih \& Tsai, 2017). In fact, this mixed research use of the flipped classroom to improve the educational process on the frequencies and measures of central tendency (mean, standard deviation and variance).

\subsection{Before the class}

Most of the students $(n=32,52.46 \%)$ consider that the activities before the class improve too much the participation of the students during the learning process. Also, the consultation of YouTube videos improves too much $(n=35,57.38 \%)$ the assimilation of knowledge. The results of machine learning on $\mathrm{H} 1$ are greater than the value of 0.480 , therefore, the participation of the students before the class positively influences the assimilation of knowledge through the consultation of the YouTube videos. In addition, the decision tree technique identifies 10 conditions for PM1 with an accuracy of $88.52 \%$.

Most of the students $(n=29,47.54 \%)$ consider that the consultation of YouTube videos improves too much the development of mathematical skills. The results of machine learning on $\mathrm{H} 2$ are greater than the value of 0.610 , therefore, the participation of the students before the class positively influences the development of mathematical skills through the consultation of the YouTube videos. In addition, data science identifies 12 conditions for PM2 with an accuracy of $81.97 \%$. 


\subsection{During the class}

Most of the students $(n=45,73.77 \%)$ consider that the activities during the class improve too much the participation of the students during the learning process. Also, the performance of the collaborative exercises and use of the spreadsheet improve too much $(n=42,68.85 \%)$ the assimilation of knowledge.

The results of machine learning on $\mathrm{H}_{3}$ are greater than the value of 0.770 , therefore, the participation of the students during the class positively influences the assimilation of knowledge through the performance of the collaborative exercises and use of the spreadsheet. In addition, data science identifies 7 conditions for $\mathrm{PM}_{3}$ with an accuracy of $90.16 \%$.

Most of the students $(n=43,70.49 \%)$ consider that the performance of the collaborative exercises and use of the spreadsheet improve too much the development of mathematical skills. The results of machine learning on $\mathrm{H}_{4}$ are greater than the value of 0.720 , therefore, the participation of the students during the class positively influences the development of mathematical skills through the performance of the collaborative exercises and use of the spreadsheet. In addition, the decision tree technique identifies 13 conditions for predictive model 4 with an accuracy of $93.44 \%$.

\subsection{After the class}

Most of the students $(n=35,57.38 \%)$ think that the activities after the class improve too much the participation of the students during the learning process. Also, the performance of the laboratory practices through the spreadsheet improves too much ( $\mathrm{n}=32,52.46 \%$ ) the assimilation of knowledge.

The results of machine learning on $\mathrm{H}_{5}$ are greater than the value of 0.490 , therefore, the participation of the students after the class positively influences the assimilation of knowledge through the performance of the laboratory practices. Also, the decision tree technique identifies 17 conditions for the predictive model 5 with an accuracy of $88.52 \%$.

Most of the students $(n=32,52.46 \%)$ think that the performance of the laboratory practices through the spreadsheet improves too much the development of mathematical skills. The results of machine learning on $\mathrm{H} 6$ are greater than the value of 0.530 , therefore, the participation of the students after the class positively influences the development of mathematical skills through the performance of the 
laboratory practices. Also, data science identifies 13 conditions for predictive model 6 with an accuracy of $86.89 \%$.

\subsection{Perceptions of the students}

Technological advances and pedagogical models are changing the behavior of the students and teachers. For example, the students of the Statistical Instrumentation for Business course think that the flipped classroom facilitates the teaching-learning process on frequencies and measures of central tendency. The active participation of the students before, during and after the class improves the assimilation of knowledge on statistics and develops the mathematical skills through the consultation of the YouTube videos, performance of the collaborative exercises and realization of the laboratory practices.

In the 21st century, flipped classroom facilitates the organization of creative activities where students are the main actor during the learning process. In particular, the consultation of the YouTube videos, performance of the collaborative exercises and realization of the laboratory practices allow the creation of new educational spaces.

This mixed research shares the ideas of various authors (e.g., Blau \& Shamir, 2017; Lo, Lie, \& Hew, 2018) on the fundamental role of the flipped classroom to improve the teaching-learning conditions. In fact, teachers can create new activities before, during and after the class through the flipped classroom.

Technological tools play a fundamental role during the realization of the learning process inside and outside the classroom. For example, the use of the videos and spreadsheet in the school activities improved the teaching-learning process on statistics. Finally, the flipped classroom is a pedagogical model that allows the development of competencies and facilitates the creation of student-centered activities through the use of ICTs (Blau \& Shamir, 2017; Lo, Lie, \& Hew, 2018; Wang, 2017). 


\section{Conclusions}

Educational institutions have the possibility to update the activities through the use of a flipped classroom. In particular, this research improved the teaching-learning process on statistics through the consultation of the YouTube videos before the class, performance of the collaborative exercises and use of the spreadsheet during the class and performance of the laboratory practices through the spreadsheet after the class.

The results of machine learning indicate that the participation of the students before, during and after the class positively influences the assimilation of knowledge and development of mathematical skills. Likewise, data science identifies 6 predictive models on the use of flipped classroom in the educational context through the decision tree technique.

The flipped classroom is a pedagogical model that allows the creation of new educational experiences. For example, the activities carried out inside and outside the classroom promote the participation of the students and improve the teachinglearning process on frequencies and measures of central tendency (mean, standard deviation and variance).

This research recommends the use of flipped classroom in the field of statistics because this pedagogical model allows innovating and updating the teaching-learning activities through ICTs. In fact, the consultation of YouTube videos, the performance of the collaborative exercises and realization of the laboratory practices allow the construction of new educational spaces that increase the motivation of the students during the learning process.

The limitations of this mixed research are the implementation of the flipped classroom in the educational field through the consultation of the YouTube videos and the use of the spreadsheet. Therefore, future research can analyze the impact of flipped classroom considering web 2.0 tools, web simulators, digital games, social networks, digital presentations, social networks and online questionnaires. Likewise, teachers can use flipped classroom considering distance education due to the conditions caused by Covid-19.

Finally, the flipped classroom has a fundamental role to meet the educational demands and expectations of the society in the 21st century. In particular, this pedagogical model improved the teaching-learning conditions in the field of statistics through the use of ICTs before, during and after the class. 


\section{References}

Blau, I. \& Shamir Inbal, T. (2017). Re-designed flipped learning model in an academic course: The role of co-creation and co-regulation. Computers \& Education, 115, 69-81.

http://dx.doi.org/10.1016/j.compedu.2017.07.014

Burke, A. S. \& Fedorek, B. (2017). Does flipping promote engagement?: A comparison of a traditional, online, and flipped class. Active Learning in Higher Education, 18(1), 11-24. https://doi.org/10.1177/1469787417693487

Burgoyne, S. \& Eaton, J. (2018). The Partially Flipped Classroom: The Effects of Flipping a Module on Junk Science in a Large Methods Course. Teaching of Psychology, 45(2), 154-157. https://doi.org/10.1177/0098628318762894

Chan, S. Y., Lam, Y. K., \& Ng, T. F. (2020). Student's perception on initial experience of flipped classroom in pharmacy education: Are we ready? Innovations in Education and Teaching International, 57(1), 62-73. https://doi.org/10.1080/14703297.2018.1541189

Chen, L. L. (2016). Impacts of Flipped Classroom in High School Health Education. Journal of Educational Technology Systems, 44(4), 411-420. https://doi.org/10.1177/0047239515626371

Chen, S. C., Yang, S. J., \& Hsiao, C. C. (2016). Exploring student perceptions, learning outcome and gender differences in a flipped mathematics course. British Journal of Educational Technology, 47(6), 1096-1112. https://doi.org/10.1111/bjet.12278

Chen,Y., Wang, Y., Kinshuk, C., \& Chen, N. S. (2014). Is FLIP enough? Or should we use the FLIPPED model instead? Computers \& Education, 79, 16-27.

http://dx.doi.org/10.1016/j.compedu.2014.07.004

Craft, E. \& Linask, M. (2020). Learning effects of the flipped classroom in a principles of microeconomics course. The Journal of Economic Education, 51(1), 1-18. https://doi.org/10.1080/00220485.2019.1687372

Deng, J. D., \& Purvis, M. K. (2015). Teaching Service Modelling to a Mixed Class: An Integrated Approach. Informatics in Education, 14(1), 35-50. http://dx.doi.org/10.15388/infedu.2015.03

Hall, A. A. \& DuFrene, D. D. (2015). Best Practices for Launching a Flipped Classroom. Business and Professional Communication, 79(2), 234-242. https://doi.org/10.1177/2329490615606733

Ignatova, N., Dagiene, V., \& Kubilinskiene, S. (2015). ICT-based Learning Personalization Affordance in the Context of Implementation of Constructionist Learning Activities. Informatics in Education, 14(1), 51-65. http://dx.doi.org/10.15388/infedu.2015.04

Karolcik, S., Cipkova, E., Hrusecky, R., \& Veselsky, M. (2015). The Comprehensive Evaluation of Electronic Learning Tools and Educational Software (CEELTES). Informatics in Education, 14(2), 243-264.

Krouss, P. \& Lesseig, K. (2020). Effects of a Flipped Classroom Model in an Introductory College Mathematics Course. Primus, 30(5), 617-635. https://doi.org/10.1080/10511970.2019.1625471

Liu, L. (2019). Face-to-face Teaching in the Flipped Classroom Supported by Visualization Tools Taking the course of "Architectural Design of Housing" as an Example. International Journal of Emerging Technologies in Learning, 14(3), 220-233. https://doi.org/10.3991/ijet.v14io3.10106

Lo, C. K., Lie, C. W., \& Hew, K. F. (2018). Applying First Principles of Instruction as a design theory of the flipped classroom: Findings from a collective study of four secondary school subjects. Computers \& Education, 118, 150-165. https://doi.org/10.1016/j.compedu.2017.12.003 
Morin, J., Tamberelli, F., \& Buhagiar, T. (2020). Educating business integrators with a computerbased simulation game in the flipped classroom. Journal of Education for Business, 95(2), 121-128. https://doi.org/10.1080/08832323.2019.1613951

Ortiz-Colon, A. M, Muñoz-Galiano, I. M., \& Colmenero-Ruiz, M. J. (2017). Impact of the Flipped Classroom Model and Collaborative Learning in Childhood Teaching University Degree. Journal of e-Learning and Knowledge Society, 13(3), 131-143. https://doi.org/10.20368/1971-8829/1358

Sadeck, O. \& Cronje, J. (2017). A Continuum of Teachers' e-Learning Practices. Electronic Journal of e-Learning, 15(5), 396-409.

Salas-Rueda, R. A. (2020). Design, Construction and Evaluation of a Web Application for the Teaching-Learning Process on Financial Mathematics. International Journal of Emerging Technologies in Learning, 15(8), 100-115. https://doi.org/10.3991/ijet.v15io8.12275

Salas-Rueda, R. A., Salas-Rueda, E. P., \& Salas-Rueda, R. D. (2020). Analysis and design of the web game on descriptive statistics through the ADDIE model, data science and machine learning. International Journal of Education in Mathematics, Science and Technology, 8(3), 245-26o. https://doi.org/10.46328/ijemst.v8i3.759

Shih, W. L. \& Tsai, C. Y. (2017). Students' perception of a flipped classroom approach to facilitating online project-based learning in marketing research courses. Australasian Journal of Educational Technology, 33(5), 32-49. https://doi.org/10.14742/ajet.2884

Sun, Y. C. (2017). Flipping every student? A case study of content-based flipped language classrooms. E-Learning and Digital Media, 14(1), 20-37. https://doi.org/10.1177/2042753017692428

Turra, H., Carrasco, V., González, C., Sandoval, V., \& Yáñez, S. (2019). Flipped classroom experiences and their impact on engineering students' attitudes towards university-level mathematics. Higher Education Pedagogies, 4(1), 136-155.

https://doi.org/10.1080/23752696.2019.1644963

Uyanga, S. (2014). Baseline Analysis on ICT in General Education of Mongolia. Informatics in Education, 13(1), 121-140.

Wang, F. H. (2017). An exploration of online behaviour engagement and achievement in flipped classroom supported by learning management system. Computers \& Education, 114, 79-91. http://dx.doi.org/10.1016/j.compedu.2017.06.012

Zahrani, A. M. (2015). From passive to active: The impact of the flipped classroom through social learning platforms on higher education students' creative thinking. British Journal of Educational Technology, 46(6), 1133-1148. https://doi.org/10.1111/bjet.12353

Zainuddin, Z. \& Perera, C. J. (2019). Exploring students' competence, autonomy and relatedness in the flipped classroom pedagogical model. Journal of Further and Higher Education, 43(1), 115-126. https://doi.org/10.1080/0309877X.2017.1356916 